\title{
AL-AWQAF
}

Jurnal Wakaf dan Ekonomi Islam

Vol. 14, No. 1, Tahun 2021

\section{Hak Guna Bangunan di Atas Tanah Wakaf sebagai Terobosan Baru Pemberdayaan Tanah Wakaf Secara Produktif}

\author{
Fahrul Fauzi $^{1}$, Lutfi Djoko Djumeno ${ }^{2}$ \\ ${ }^{1}$ Universitas Indonesia, Depok, fahrul.fauzi@ui.ac.id \\ ${ }^{2}$ Universitas Indonesia, Jakarta, 1.sriyono@gmail.com
}

\begin{abstract}
The purpose of this research is to provide an idea of how to realize the potential application of the concept of granting the right to build on waqf land. This concept is a new thing that can add value to waqf land so that it can be optimized productively without losing the basic essence of waqf itself. The research method used in writing this article is normative legal research. Using primary legal materials in the form of legislation on waqf and land rights, as well as secondary legal materials in the form of scientific articles related to waqf and land rights. The data analysis technique used in organizing the available data is a qualitative data analysis technique. This study found that waqf land has similarities in practice and concept to the right of management. So, if land managed properly can be granted the right to build, Wagf land can also be granted the right to build. The benefits of implementing this concept in the future could be felt by developers, nazhir, and the general public. Developers get benefits in the form of freedom from land acquisition costs and can guarantee the right to build on waqf land. Nazhir gets benefits in the form of land use fees and recommendation fees that must be paid by the developer as a condition for using waqf land and for certification purposes. Then the profits received by Nazhir can be used for the welfare of the people according to the waqf pledge.
\end{abstract}

Keywords: Waqf, Waqf Land, Right to Build, Right of Management.

\begin{abstract}
Abstrak: Penelitian ini bertujuan memberikan suatu ide dan gagasan dalam mewujudkan potensi diterapkannya konsep pemberian hak guna bangunan di atas tanah wakaf. Konsep ini merupakan hal baru yang dapat menambah nilai dari tanah wakaf sehingga dapat dioptimalkan secara produktif tanpa menghilangkan esensi dasar dari wakaf itu sendiri. Metode penelitian yang digunakan dalam penulisan artikel ini adalah penelitian hukum normatif. Menggunakan bahan hukum primer berupa perundang-undangan tentang wakaf dan hak atas tanah, serta bahan hukum sekunder berupa artikel ilmiah yang berkaitan dengan wakaf dan hak atas tanah. Teknis analisis data yang digunakan dalam mengorganisir data-data tersedia adalah teknis analisis data kualitatif. Penelitian ini menemukan bahwa tanah wakaf memiliki kesamaan dalam praktik dan konsep dengan tanah hak pengelolaan. Sehingga apabila di atas tanah hak pengelolaan dapat diberikan hak guna bangunan, maka di atas tanah wakaf pun dapat diberikan hak guna bangunan. Manfaat penerapan konsep ini di kemudian hari dapat dirasakan oleh developer, nazhir, dan masyarakat secara umum. Developer mendapatkan keuntungan berupa kebebasan biaya pengadaan tanah dan dapat menjaminkan hak guna bangunan di atas tanah wakaf. Nazhir mendapatkan keuntungan berupa biaya pemanfaatan tanah dan biaya rekomendasi yang harus dibayarkan oleh developer sebagai syarat pemakaian tanah wakaf
\end{abstract}


dan untuk kepentingan sertifikasi. Kemudian keuntungan yang diterima oleh nazhir itu dapat digunakan untuk kesejahteraan umat sesuai ikrar wakaf.

Kata Kunci: Wakaf, Wakaf Tanah, Hak Guna Bangunan, Hak Pengelolaan.

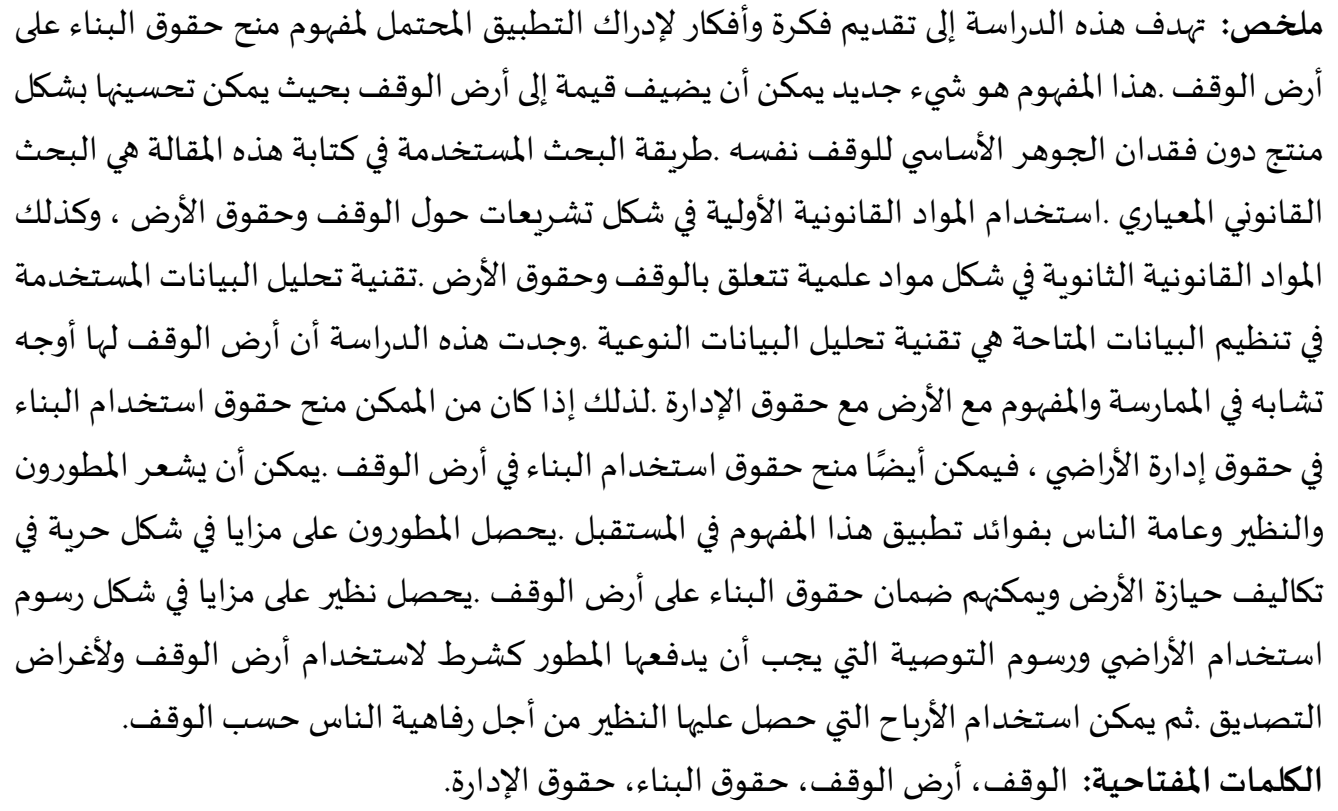

\section{Pendahuluan}

Islam merupakan agama yang mengatur kehidupan manusia secara menyeluruh atau komprehensif. Selain hubungan vertikal antara manusia dan Tuhan-Nya, Islam pun mengatur hubungan horizontal antarmanusia. Dalam hubungan antarmanusia, Islam sangat memerhatikan dimensi sosial. Beberapa hal yang diatur Islam kaitannya dengan dimensi sosial adalah zakat, infak, sedekah, dan wakaf. Wakaf dalam sejarah umat Islam mempunyai peran yang signifikan dalam membawa umat Islam pada era keemasan di berbagai lini kehidupan, baik itu sosial, ekonomi, politik, maupun ilmu pengetahuan.

Wakaf berasal dari bahasa arab, yaitu dari kata waqafa-yaqifu-waqf, yang memiliki arti "ragu-ragu, berhenti, memberhentikan, memahami, mencegah, menahan, mengatakan, memperlihatkan, meletakkan, memperhatikan, mengabdi dan tetap berdiri" (Munawwir, 1984). Dikutip dari kitab Abkam al-Waqf, Abdul Wahhab Khallaf mendefinisikan wakaf sebagai menahan sesuatu yang bersifat inderawi (hissi) maupun maknawi. Kata wakaf menurutnya juga digunakan untuk objeknya yakni dalam arti sesuatu yang ditahan. Kemudian dari kitab Subul as-Salam, Muhammad Ibn Ismail as-San'any menyebut bahwa wakaf memiliki arti menahan harta yang mungkin diambil manfaatnya tanpa menghabiskan atau merusak bendanya dan digunakan untuk kebaikan (Prihatini et al., 2005).

Wakaf merupakan lembaga yang dianjurkan oleh ajaran Islam, di mana dapat digunakan oleh seseorang sebagai sarana penyaluran rezeki yang telah diberikan oleh Allah swt kepadanya. Perkembangan wakaf di Indonesia sejalan dengan perkembangan penyebaran Islam. Pada awalawal penyebaran Islam, wakaf sangat identik dengan wakaf benda tak bergerak seperti tanah 
dan bangunan yang digunakan untuk pendirian masjid, pesantren, madrasah, dan rumah sakit. Hal ini sangat membantu para dai saat itu untuk menyerukan ajaran Islam.

Negara Indonesia sebagai negara dengan penduduk muslim terbanyak di dunia mendukung keberadaan lembaga wakaf. Keberadaan lembaga wakaf di Indonesia dapat dikatakan sangat strategis. Selain sebagai salah satu aspek ajaran Islam yang memiliki dimensi spriritual, wakaf juga merupakan lembaga yang menekankan pentingnya menjunjung kesejahteraan ekonomi dan kesejahteraan umat. Salah satu bentuk konkret dukungan pemerintah adalah dengan diterbitkannya Undang-Undang Nomor 41 Tahun 2004 tentang Wakaf (UU No. 41/2004) serta peraturan pelaksanaannya. Definisi wakaf dalam UU No. 41/2004 ialah "perbuatan hukum wakif (orang yang mewakafkan) untuk memisahkan dan/atau menyerahkan sebagian harta benda miliknya untuk dimanfaatkan selamanya atau untuk jangka waktu tertentu sesuai dengan kepentingannya guna keperluan ibadah dan/atau kesejahteraan umum menurut syariah."

Definisi wakaf dalam UU No. 41/2004 memungkinkan seseorang untuk mewakafkan hartanya dengan jangka waktu tertentu. Dengan berlakunya UU No. 41/2004 ini berkembang beberapa objek wakaf baru. Dahulu harta benda yang paling identik dengan wakaf adalah tanah dan bangunan, namun sekarang ini harta benda wakaf dapat berupa uang, logam mulia, surat berharga, kendaraan, hak atas kekayaan intelektual, hak sewa dan benda bergerak lain sesuai dengan peraturan perundang-undangan. Perkembangan beberapa objek wakaf yang baru tidak berarti objek wakaf yang lama tidak menjadi fokus utama di Indonesia. Justru tanah dan bangunan sebagai objek wakaf lama menjadi sesuatu yang perlu diberdayakan karena masyarakat Indonesia saat ini masih banyak yang menganggap bahwa wakaf adalah tanah atau dengan kata lain sebagian masyarakat belum mengenal objek wakaf lain selain tanah.

Praktik di lapangan ternyata masih banyak tanah wakaf yang terlantar atau tidak digunakan secara produktif. Berdasarkan data Badan Wakaf Indonesia, potensi aset wakaf per tahun mencapai Rp 2.000 triliun dengan luas tanah wakaf mencapai 420.000 ha (Intan, 2019). Sangat disayangkan apabila dari potensi tanah wakaf yang begitu luas dan menempati beberapa lokasi strategis tidak dimanfaatkan dan dikelola secara produktif. Padahal tanah wakaf yang luas dan strategis di berbagai lokasi sangat dimungkinkan untuk dikelola dan dikembangkan secara produktif. Misalnya tanah wakaf dapat disewakan pada developer untuk dibangun kawasan perkantoran, apartemen, rumah susun, dan lain sebagainya. Hasil dari penyewaan tersebut dapat digunakan untuk perawatan gedung wakaf atau pemberdayaan pada masyarakat dengan kondisi ekonomi lemah yang ada di sekitarnya (Djumeno \& Fauzi, 2021).

Permasalahan tanah wakaf terlantar pernah dikeluarkan Fatwa Tarjih tentang Tanah Wakaf Terlantar atas pertanyaan Majelis Wakaf dan ZIS PP Muhammadiyah, bahwa terdapat dua persoalan utama yang menyebabkan tanah wakaf menjadi terlantar: Pertama, tanah wakaf yang terlantar karena belum atau tidak adanya dana untuk membangun sesuai dengan niat wakaf. Pada persoalan ini nampaknya tujuan wakaf yang diniatkan atau diikrarkan oleh wakif sebenarnya memiliki nilai maslahat bagi masyarakat, hanya saja untuk mewujudkannya belum tersedia dana, yang menyebabkan tanah wakaf menjadi terlantar. Kedua, tanah wakaf yang terlantar karena tujuan wakaf yang diniatkan atau diikrarkan oleh wakif kurang maslahat sebab di tempat itu telah tersedia sarana yang sama dengan yang diniatkan atau diikrarkan oleh wakif. 
Dalam kasus ini, apabila tujuan wakaf yang diniatkan wakif tetap dilakukan maka dapat dipastikan bahwa harta wakaf baik tanah maupun bangunannya tidak akan mendatangkan manfaat dan kebaikan secara optimal (Hidayati, 2012).

Permasalahan mengenai dana yang belum tersedia terjadi karena developer tidak tertarik untuk mendirikan bangunan atas dasar tanah wakaf yang disewakan sebab developer tidak akan dapat menjaminkan tanah tersebut. Akan berbeda ceritanya apabila di atas tanah wakaf tersebut dapat diberikan Hak Guna Bangunan (HGB) sebagaimana halnya tanah Hak Pengelolaan (HPL). Pada tanah HPL, pemegang HPL diberikan kewenangan untuk memberikan hak-hak atas tanah di atas tanah HPL, seperti Hak Milik (HM), HGB, dan Hak Pakai (HP). Terbaru dalam UndangUndang Cipta Kerja di atas tanah HPL dapat diberikan Hak Guna Usaha (HGU).

Konsep tanah wakaf yang sebenarnya hampir serupa dengan tanah HPL, keduanya merupakan perincian status tanah-tanah negara. Prof. Boedi Harsono dalam bukunya menyatakan bahwa ditinjau dari segi kewenangan penguasaannya, terdapat kecenderungan untuk lebih memperinci status-status tanah yang semula tercakup dalam pengertian tanah-tanah negara itu menjadi (1) tanah-tanah wakaf; (2) tanah-tanah hak pengelolaan; (3) tanah-tanah hak ulayat; (4) tanah-tanah kaum; (5) tanah-tanah kawasan hutan; (6) tanah-tanah sisanya (tanah negara dalam arti sempit) (Harsono, 2018). Ditinjau dari segi kewenangan penguasaannya antara HPL dan tanah wakaf memiliki kesamaan, yaitu sama-sama perincian dari tanah negara. Oleh karena itu, penulis meneliti mengapa hanya tanah HPL yang dapat diberikan hak atas tanah lain di atasnya, mengapa tanah wakaf tidak demikian?

Penelitian ini bertujuan memberikan suatu ide dan gagasan dalam mewujudkan potensi diterapkannya konsep pemberian HGB di atas tanah wakaf. Konsep pemberian ini apabila dapat diterapkan dapat menambah nilai tambah tanah wakaf serta dapat mengoptimalkan pemanfaatan tanah wakaf secara produktif tanpa menghilangkan esensi dasar dari wakaf itu sendiri. Tulisan ini diharapkan dapat menjadi dasar dan pegangan bagi pengembang kebijakan dalam merumuskan peraturan perundang-undangan tentang wakaf khususnya pemberdayaan tanah wakaf secara produktif di kemudian hari.

\section{Studi Literatur}

\section{Pemberdayaan Tanah Wakaf}

Tanah wakaf yang luas dan menempati beberapa lokasi strategis seharusnya menjadi potensi untuk dikembangkan dan dikelola secara produktif agar mendapatkan manfaat yang optimal. Penelitian yang dilakukan oleh Hadi (2018) mengungkapkan bahwa wakaf merupakan potensi sumber dana umat yang perlu dikembangkan, didayagunakan, dan dikelola secara profesional untuk memperoleh hasil manfaat yang optimal dalam rangka mengentaskan kemiskinan dan mensejahterakan umat.

Penelitian oleh Lita \& Sandra (2018) mengatakan bahwa tanah merupakan salah satu jenis benda wakaf yang memiliki nilai ekonomi tinggi dikarenakan jumlahnya yang tidak bertambah dan akan semakin dibutuhkan manusia. Berkaitan pemberdayaan tanah wakaf dalam penelitian, dikatakan juga bahwa salah satu bentuk pengelolaan tanah wakaf yang menguntungkan secara ekonomi adalah pembangunan commercial building, dimana hasilnya dapat dimanfaatkan untuk meningkatkan kesejahteraan masyarakat. Bentuk lain pemberdayaan tanah wakaf sebagaimana 
disebutkan oleh Lita \& Utama (2016) adalah bahwa potensi tanah wakaf di Indonesia juga dapat menjadi solusi bagi penyediaan tanah untuk didirikannya rumah susun.

Selain potensi-potensi untuk memberdayakan tanah wakaf, pemberdayaan tanah wakaf juga menemui titik-titik hambatan dalam pengelolaan tanah wakaf. Sutrisno (2017) dalam penelitiannya mengatakan bahwa tanah wakaf dalam perkembangannya masih banyak terdapat masalah baik dari segi pengelolaannya, maupun dari segi pengamanan atau penguasaannya. Dalam beberapa dispute tanah wakaf di masyarakat, beberapa diantaranya terjadi peralihan penguasaan tanah wakaf yang semula merupakan aset umat berubah menjadi penguasaan milik pribadi.

Penelitian yang lain oleh Elimartati (2016) mengatakan bahwa praktik wakaf termasuk tanah wakaf yang terjadi dalam kehidupan masyarakat belum sepenuhnya berjalan tertib dan efisien, sehingga dalam beberapa kasus harta wakaf tidak terpelihara, telantar, atau beralih ke pihak ketiga secara melawan hukum. Hal tersebut menyebabkan fungsi wakaf dalam mewujudkan potensi dan manfaat ekonomis harta benda wakaf untuk kepentingan ibadah serta memajukan kesejahteraan masyarakat belum tercapai.

\section{Posisi Tanah Wakaf dalam Hukum Agraria Nasional}

Hukum Agraria Nasional sebagaimana dimuat dalam UU No. 5/1960 mengatur hak penguasaan atas tanah. Prof. Boedi Harsono menyatakan bahwa hak penguasaan atas tanah memiliki beberapa wewenang, kewajiban, maupun larangan bagi pemegang haknya untuk berbuat terhadap tanah yang dihaki. Sesuatu yang dibolehkan, diwajibkan, ataupun dilarang untuk diperbuat terhadap hak atas tanah menjadi tolak ukur pembeda antara hak atas tanah yang satu dengan hak atas tanah yang lainnya (Harsono, 2018). Lebih lanjut Prof. Boedi Harsono mengatakan bahwa hak penguasaan atas tanah memiliki jenjang hierarki sebagai berikut:

Tabel 1. Hierarki Hak Penguasaan Atas Tanah

\begin{tabular}{|c|c|l|}
\hline No & Indikator & \multicolumn{1}{c|}{$\begin{array}{c}\text { Tanah Wakaf } \\
\text { Tanah HPL }\end{array}$} \\
\hline 1 & Hak Bangsa Indonesia & $\begin{array}{l}\text { Memiliki arti bahwa semua tanah yang masuk dalam } \\
\text { teritorial wilayah NKRI merupakan kepunyaan bangsa } \\
\text { Indonesia. }\end{array}$ \\
\hline 2 & Hak Menguasai Negara & $\begin{array}{l}\text { Negara sebagai organisasi kekuasaan tertinggi diberikan } \\
\text { tugas oleh hukum tanah nasional untuk dapat } \\
\text { mengendalikan atau mengarahkan fungsi bumi, air, dan } \\
\text { ruang angkasa sesuai kebijaksanaan pemerintah. }\end{array}$ \\
\hline 3 & Hak Ulayat Masyarakat & $\begin{array}{l}\text { Serangkaian wewenang dan kewajiban suatu masyarakat } \\
\text { hukum adat yang berhubungan dengan tanah yang } \\
\text { terletak dalam lingkungannya. Pengakuan terhadap Hak } \\
\text { ulayat ini terus berlangsung sepanjang menurut } \\
\text { kenyataannya masih ada. }\end{array}$ \\
\hline 4 & Hukum Adat & $\begin{array}{l}\text { Terdiri dari: } \\
\text { 1) Hak Atas Tanah Orisinal (primer): HM, HGU, } \\
\text { HGB, dan HP yang diberikan oleh Negara. }\end{array}$ \\
& $\begin{array}{l}\text { Hak Atas Tanah Derivatif (sekunder): HGU atau } \\
\text { HP yang diberikan pemilik tanah HM, Hak Sewa, }\end{array}$ \\
\hline
\end{tabular}




\begin{tabular}{|l|l|l|l|}
\hline & & Hak Gadai, Hak Usaha Bagi Hasil, Hak \\
& & Menumpang, dll. & \\
& 3) Tanah Wakaf & & \\
& 4) & Hak Jaminan Tanah, yaitu Hak Tanggungan & \\
\hline
\end{tabular}

Prof. Boedi Harsono juga dalam bukunya menyatakan bahwa ditinjau dari segi kewenangan penguasaan tanahnya, tanah wakaf termasuk dari perincian dari tanah negara. Secara lengkap dikatakan bahwa terlihat kecenderungan dalam memperinci status-status tanah yang semula tercakup dalam pengertian tanah-tanah negara itu menjadi antara lain: (1) tanah-tanah wakaf; (2) tanah-tanah HPL; (3) tanah-tanah hak ulayat; (4) tanah-tanah kaum; (5) tanah-tanah kawasan hutan; (4) tanah-tanah sisanya (tanah negara dalam arti sempit) (Harsono, 2018).

Santoso (2014) berpendapat mengenai jengjang hierarki yang dikatakan oleh Prof. Boedi Harsono yang mana menunjukkan bahwa tanah wakaf merupakan termasuk salah satu hak penguasaan atas tanah yang bersifat perorangan, dimana di dalamnya terdapat wewenang, kewajiban, dan larangan bagi pemegang tanah wakaf. Santoso (2014) menuturkan bahwa wakaf tanah merupakan penggunaan tanah untuk kepentingan keagamaan, khususnya Islam. Lebih lanjut ia menguraikan bahwa UU No. 5/1960 memperhatikan nilai-nilai keagamaan dapat dilihat dari beberapa hal berikut: (1) Konsiderans UU No. 5/1960 di bawah perkataan berpendapat huruf a; (2) Konsiderans UU No. 5/1960 di bawah perkataan berpendapat huruf c; (3) Pasal 5 UU No. 5/1960; (4) Pasal 14 ayat (1) UU No. 5/1960; dan (5) Pasal 49 UU No. $5 / 1960$.

Lubis \& Lubis (2008) mengatakan bahwa masalah wakaf tanah mendapat tempat tersendiri dalam aturan hukum di bidang keagrariaan Indonesia. Hal tersebut yang menurutnya mengapa UU No. 5/1960 memandang masalah wakaf ini diatur secara tersendiri dalam Pasal 49 ayat (3). Dengan demikian dapat dikatakan bahwa tanah wakaf dalam hukum agraria nasional memiliki posisi yang sangat penting dan diperhatikan, oleh karenanya ditempatkan dalam tatanan hak atas tanah hukum agraria Indonesia.

\section{Metode Penelitian}

Metode penelitian yang digunakan penulisan artikel ini adalah metode penelitian hukum normatif. Penelitian hukum merupakan kegiatan ilmiah berdasarkan pada metode, sistematika, dan pemikiran tertentu yang memiliki tujuan untuk mempelajari satu atau beberapa gejala hukum tertentu dengan cara menganalisisnya. Pada penelitian hukum normatif, peneliti hanya menggunakan bahan pustaka atau data sekunder yang terdiri dari bahan hukum primer, bahan hukum sekunder, dan bahan hukum tersier yang mengatur atau membahas mengenai tanah wakaf (Soekanto, 1986).

Bahan hukum primer yang menjadi dasar dari penelitian ini yaitu UU No. 41/2004 tentang Wakaf, UU No. 5/1960 tentang Peraturan Dasar Pokok-Pokok Agraria (UUPA), UU No. 11/2020 tentang Cipta Kerja, PP No. 42/2006 tentang Pelaksanaan UU Wakaf, PP No. 18/2021 tentang Hak Pengelolaan, Hak Atas Tanah, Satuan Rumah Susun, \& Pendaftaran Tanah, Permenag No. 73/2013 tentang Tata Cara Perwakafan Benda Tidak Bergerak \& Benda Bergerak Selain Uang, dan Kompilasi Hukum Islam (KHI). 
Bahan hukum sekunder yang menjadi rujukan dari penelitian ini, antara lain: pertama, buku yang ditulis Prof. Boedi Harsono berjudul "Hukum Agraria Indonesia: Sejarah Pembentukan Undang-Undang Pokok Agraria - Isi dan Pelaksanaannya"; kedua, buku yang ditulis Farida Prihatini dkk berjudul "Hukum Islam Zakat dan Wakaf: Teori dan Praktiknya di Indonesia"; serta beberapa buku dan jurnal ilmiah lain yang secara spesifik membahas berkaitan dengan wakaf tanah dan perkembangannya di Indonesia. Kemudian bahan hukum tersier yang digunakan dalam penelitian ini adalah kamus hukum.

Teknis analisis data yang digunakan dalam penelitian ini adalah teknis analisis data kualitatif. Penulis melakukan penulisan dengan cara mengorganisasikan data-data yang didapatkan dari bahan hukum yang menjadi sumber penulisan ini. Kemudian memilahnya menjadi satuan yang dapat dikelola, mensintesiskan, mencari dan menemukan pola, menemukan sesuatu yang penting untuk dipelajari, dan memutuskan apa yang dapat dituliskan sehingga mudah dipahami oleh pembaca tulisan ini (Moleong, 2017).

\section{Hasil Dan Pembahasan}

\section{Tanah Wakaf Sebagai Wakaf yang Produktif}

Pasal 215 ayat (1) KHI mengartikan "wakaf sebagai perbuatan hukum seseorang atau kelompok orang atau badan hukum yang memisahkan sebagian dari benda miliknya dan melembagakannya untuk selama-lamanya guna kepentingan ibadah atau keperluan umum lainnya sesuai dengan ajaran Islam". Indonesia sebagai negara dengan penduduk muslim terbanyak di dunia harus terus mendukung keberadaan lembaga wakaf yang sangat strategis ini. Dikatakan sangat strategis dikarenakan wakaf merupakan satu diantara banyak aspek ajaran Islam yang memiliki dimensi spriritual, wakaf pun menjadi lembaga yang menitikberatkan akan urgensi menjunjung kesejahteraan ekonomi maupun kesejahteraan umat (welfare state).

Melihat lembaga wakaf yang sangat potensial untuk dikembangkan dan sebagai bentuk konkret dukungan pemerintah, pemerintah telah membentuk UU No. 41/2004 serta peraturan pelaksanaannya. UU No. 41/2004 mendefinisikan wakaf sebagai "perbuatan hukum wakif (orang yang mewakafkan) untuk memisahkan dan/atau menyerahkan sebagian harta benda miliknya untuk dimanfaatkan selamanya atau untuk jangka waktu tertentu sesuai dengan kepentingannya guna keperluan ibadah dan/atau kesejahteraan umum menurut syariah.”

Berbicara mengenai objek wakaf, harta benda wakaf hanya dapat diwakafkan apabila dimiliki dan dikuasai oleh wakif secara sah. Tanah merupakan salah satu objek wakaf yang termasuk dalam kategori benda tak bergerak. Yang termasuk benda tidak bergerak menurut Pasal 16 ayat (2) UU No. 41/2004 meliputi: "(a) hak atas tanah sesuai dengan ketentuan peraturan perundang-undangan yang berlaku baik yang sudah maupun yang belum terdaftar; (b) bangunan atau bagian bangunan yang berdiri di atas tanah sebagaimana dimaksud pada huruf a; (c) tanaman dan benda lain yang berkaitan dengan tanah; (d) hak milik atas satuan rumah susun sesuai dengan ketentuan peraturan perundang-undangan yang berlaku; (e) benda tidak bergerak lain sesuai dengan ketentuan syariah dan peraturan perundang-undangan yang berlaku."

UU No. 41/2004 menyebutkan bahwa "hak atas tanah sesuai dengan ketentuan peraturan perundang-undangan yang berlaku baik yang sudah maupun yang belum terdaftar", belum 
disebutkan secara detail hak atas tanah apa saja yang dapat menjadi objek wakaf. Kemudian dalam peraturan pelaksanaan UU No. 41/2004 yaitu PP No. 42/2006 disebutkan dalam Pasal 17 bahwa hak atas tanah yang dapat diwakafkan antara lain: “(a) HM baik yang sudah atau belum terdaftar; (b) HGB, HGU atau HP di atas tanah negara; (c) HGB atau HP di atas HPL atau HM wajib mendapat izin tertulis pemegang hak pengelolaan atau hak milik; (d) HMSRS." (Fauzi, 2019)

Lahirnya UU No. 41/2004 menyebabkan perluasan objek wakaf berupa tanah yang dapat diwakafkan. Apabila dahulu wakaf atas tanah hanya dapat dilakukan terhadap tanah HM, saat ini dapat pula diberlakukan pada HGB, HGU, HP, HMSRS, dan hak atas tanah lain di atas tanah HPL atau HM dengan izin pemegang HPL atau HM. Prof. Boedi Harsono mengatakan bahwa perwakafan tanah ialah perbuatan hukum suci, mulia, dan terpuji, yang dilakukan oleh seseorang atau badan hukum, dengan memisahkan sebagian dari harta kekayaannya yang berupa hak atas tanah dan melembagakannya untuk selama-lamanya menjadi "wakaf sosial", yaitu wakaf yang diperuntukan bagi kepentingan peribadatan atau keperluan umum lainnya, sesuai dengan ajaran agama Islam (Harsono, 2018).

Tanah wakaf sejak berlakunya PP No. 24/1997 tentang Pendaftaran Tanah merupakan salah satu hak atas tanah yang wajib untuk didaftarkan. Tanah wakaf perlu dicatat dan didaftarkan dalam rangka memberikan kepastian hukum terhadap tanah wakaf yang bersangkutan, dan menghindarkan berbagai sengketa yang dimungkinkan akan muncul di kemudian hari. Tanah wakaf yang telah didaftarkan akan diterbitkan Sertipikat Tanah Wakaf atas nama nazhir yang dikeluarkan oleh Kepala Kantor Pertanahan. Berdasarkan ketentuan Pasal 32 ayat (1) PP 24/1997, sertipikat merupakan surat tanda bukti hak yang berlaku sebagai alat pembuktian yang kuat. Dikuatkan lagi berdasarkan Putusan MA tanggal 3 November 1971 No. 383/K/Sip/1971 disebut bahwa pengadilan tidak berwenang untuk membatalkan sertipikat, karena hal termasuk dalam kewenangan administrasi.

Anggapan tanah wakaf yang identik sebagai objek wakaf non-produktif. Anggapan ini sepenuhnya salah, wakaf pertanahan dapat juga menjadi wakaf produktif apabila pengelolaan dan manajemen yang mengurusnya mengerti akan esensi wakaf produktif. Diundangkannya UU No. 41/2004 merupakan langkah konkrit yang ingin membawa semangat wakaf produktif di Indonesia (Khusaeri, 2015). Namun karena definisi wakaf produktif tidak dijelaskan secara eksplisit dalam UU No. 41/2004 maka perlu dikaji terlebih dahulu mengenai wakaf produktif.

Secara bahasa produktif berarti "bersifat atau mampu meghasilkan, mendatangkan hasil, manfaat dan menguntungkan.” Munzir Qahaf membagi penggunaan wakaf menjadi dua, yaitu wakaf yang digunakan secara langsung dan tidak langsung (Qahaf, 2005). Wakaf jenis pertama adalah wakaf yang pokok barangnya digunakan untuk mencapai tujuan seperti masjid untuk shalat, sekolah untuk belajar, rumah sakit untuk layanan kesehatan. Wakaf jenis ini disebut wakaf konsumtif. Sedangkan wakaf jenis kedua, pokok barangnya tidak digunakan secara langsung, melainkan dikelola untuk menghasilkan sesuatu, kemudian hasil yang diperoleh disedekahkan. Wakaf yang demikian disebut sebagai wakaf produktif. Ahli lain, Jaih Mubarak menyatakan wakaf produktif adalah transformasi dari pengelolaan wakaf yang alami menjadi pengelolaan wakaf yang profesional untuk meningkatkan atau menambah manfaat wakaf (Mubarok, 2008). Dari pendapat kedua ahli tersebut dapat disimpulan bahwa wakaf produktif 
tidak diartikan secara baku sebagai penambahan kuantitas melainkan bisa juga secara kualitas seperti manajemen pengelolaan wakaf.

Manajemen dan pengelolaan wakaf di Indonesia memiliki sejarah yang panjang. Dikutip dari Direktorat Pemberdayaan Wakaf, setidaknya pengelolaan wakaf di Indonesia dibagi menjadi tiga periode besar sejarah sebagai berikut (Hanna, 2015):

Pertama, periode tradisional. Pada masa ini wakaf masih dianggap ajaran murni yang termasuk dalam kategori ibadah mahdhah. Pada periode ini hampir semua objek wakaf merupakan benda berwujud fisik misalnya mushola, masjid, makam, dan pesantren. Maka dari itu, eksistensi lembaga wakaf belum dapat berkontribusi secara luas sebab sifat objek wakaf yang ada saat itu sifatnya konsumtif.

Kedua, periode semi profesional. Manajemen pengelolaan wakaf kondisinya hampir serupa dengan periode tradisional, namun sudah ada pengembangan pola atau bentuk pemberdayaan wakaf secara produktif walaupun implementasinya belum optimal. Contohnya ialah dibangunnya masjid wakaf di tempat yang strategis dan menambah bangunan untuk aula pertemuan sehingga dapat disewa untuk acara pernikahan dan lainnya.

Ketiga, periode profesional. Pada periode ini potensi wakaf mulai dilirik dan dianggap menarik untuk diberdayakan dengan profesional-produktif. Profesional yang dimaksud adalah meliputi aspek manajemen, pola kemitraan usaha, sumber daya manusia, objek wakaf sudah mulai meluas, dan telah mendapatkan dukungan (political will) dari pemerintah secara penuh. Salah satu dukungan pemerintah dalam hal ini adalah diterbitkannya UU No. 41/2004 dan Fatwa MUI.

Konsep wakaf produktif tetap dapat diterapkan dalam mewakafkan tanah. Salah satu konsep konsep yang dapat diterapkan dalam rangka menjadi wakaf tanah yang produktif adalah pemberian HGB di atas tanah wakaf. Pemberian HGB tidak akan menghilangkan status tanah wakaf itu sendiri, melainkan HGB yang lahir berdiri di atas tanah wakaf, sehingga ketika jangka waktu HGB habis, tanah tersebut kembali menjadi tanah wakaf yang dikelola nazhir. Konsep ini merupakan konsep wakaf produktif yang dimungkinkan dapat menjadi solusi bagi tanahtanah wakaf yang masih banyak dikelola secara konsumtif atau bahkan telantar.

\section{Pengaturan HGB dalam Peraturan Perundang-undangan}

HGB diatur dan disebutkan secara eksplisit dalam Pasal 16 ayat (1) huruf c UUPA. Secara khusus pengaturan HGB diatur dalam Pasal 35 hingga Pasal 40 UUPA. Lebih detail, pengtaturan HGB diatur dalam PP No. 18/2021 khususnya Pasal 34 hingga Pasal 48. UUPA mendefinisikan HGB sebagai "hak untuk mendirikan dan mempunyai bangunan-bangunan atas tanah yang bukan miliknya sendiri, dengan jangka waktu paling lama 30 tahun." Dari pengertian tersebut terkandung unsur-undur dari HGB antara lain bahwa (a) HGB adalah hak untuk mendirikan dan mempunyai bangunan; (b) tanah HGB berasal dari tanah yang bukan milik pemegang HGB; (c) HGB memiliki jangka waktu penguasaan.

Dalam HGB terdapat pemisahan antara pemilikan atas bangunan dan tanah di bawahnya. Bangunan menjadi milik pemegang HGB sedangkan tanahnya milik pihak lain. Benda-benda 
yang dapat dikategorikan sebagai bangunan antara lain: rumah tempat tinggal atau hunian, ruko, rukan, rumah sakit/pusat kesehatan masyarakat, restoran, rumah susun, apartemen, hotel, pabrik, gudang, dan lain sebagainya (Santoso, 2017).

Saat ini berdasarkan Pasal 36 PP No. 18/2021 menetapkan bahwa tanah yang di atasnya dapat diberikan HGB adalah tanah negara, tanah HPL, dan tanah HM. Tanah wakaf yang menjadi fokus utama penulis dalam penelitian ini belum merupakan tanah yang di atasnya dapat diberikan HGB hal tersebut dikarenakan pemikiran lama yang menganggap harta benda wakaf haruslah abadi. Padahal pemberian HGB di atas tanah wakaf tidak menjadikan tanah wakaf yang bersangkutan menjadi hilang, tanah wakaf yang bersangkutan tetap ada, yang menjadi hilang atau dialihkan adalah HGB di atas tanah wakaf tersebut. Apabila HGB di atas tanah wakaf sudah habis jangka waktunya maka tanah tersebut akan kembali menjadi tanah wakaf yang dikelola oleh nazhir.

Subjek hukum yang dapat menguasai HGB antara lain WNI dan badan hukum yang didirikan berdasarkan hukum Indonesia dan berkedudukan di Indonesia (BHI). WNA yang berkedudukan di Indonesia atau badan hukum asing yang mempunyai perwakilan tidak dapat menjadi pemegang HGB di Indonesia. Pengaturan mengenai subjek hukum yang dapat menguasai tanah ini sangatlah baku apabila subjek hukum atas tanah tidak sesuai atau tidak berhak atas tanah maka tanah tersebut harus dilepaskan. Hal itu dikarenakan dalam hukum tanah nasional terdapat prinsip "status subjek menentukan status tanah yang dapat dikuasainya."

HGB terjadi atau tercipta dikarenakan dua hal, yaitu (1) Apabila terhadap tanah yang dikuasai langsung oleh negara, HGB tercipta karena keputusan pemberian hak oleh Menteri; (2) Apabila di atas tanah HPL, HGB tercipta karena keputusan pemberian hak oleh Menteri berdasarkan persetujuan pemegang HPL; (3) Apabila di atas tanah HM, HGB tercipta melalui pemberian hak oleh pemegang HM dengan akta yang dibuat oleh PPAT.

HGB atas tanah negara dan tanah HPL dapat diberikan untuk jangka waktu paling lama 30 (tiga puluh) tahun. Yang atas permintaan pemegang hak dan mengingat keperluan dan keadaan bangunan-bangunannya jangka waktu HGB dapat diperpanjang dengan jangka waktu paling lama 20 (dua puluh) tahun. Serta dapat diperbaharui haknya untuk jangka waktu paling lama 30 (tiga puluh) tahun. Sedangkan HGB diatas tanah HM dapat diberikan paling lama 30 (tiga puluh) tahun serta dapat diperbaharui dengan akta pemberian HGB yang baru oleh pemegang HM.

Kewajiban pemegang HGB berdasarkan Pasal 42 PP No. 18/2021 antara lain: (a) melaksanakan pembangunan atau mengusahakan tanahnya sesuai peruntukannya; (b) memelihara kesuburan tanah dan mencegah kerusakannya; (c) menjaga fungsi konservasi sempadan badan air; (d) mematuhi ketentuan pemanfaatan ruang yang diatur dalam rencana tata ruang; (e) melepaskan hak atas tanah apabila akan dipergunakan untuk kepentingan umum; (f) menyerahkan kembali tanah kepada negara, pemegang HPL, atau pemegang HM apabila jangka waktunya telah habis.

Selain kewajiban, pemegang HGB berdasarkan Pasal 44 PP 18/2021 juga memiliki hak antara lain: (a) menggunakan dan memanfaatkan tanah sesuai peruntukannya dan persyaratan 
sebagaimana dalam keputusan pemberian haknya; (b) mendirikan dan memiliki bangunan di atas tanah yang diberikan sepanjang untuk keperluan pribadi atau mendukung usaha sesuai perundang-undangan; (c) melakukan perbuatan hukum yang bermaksud melepaskan, mengalihkan, dan mengubah penggunaannya serta membebankan dengan hak tanggunan sesuai perundang-undangan.

\section{Konsep Pemberian HGB di atas Tanah Wakaf}

UUPA berpangkal pada pendirian bahwa untuk mencapai apa yang telah ditentukan dalam Pasal 33 ayat (3) Undang Undang Dasar 1945 (UUD 1945), bangsa Indonesia sebagai suatu negara tidak perlu bertindak sebagai pemilik tanah. Alangkah lebih tepat jika menempatkan dan memberikan kedudukan negara sebagai organisasi kekuasaan dari seluruh rakyat (bangsa) bertindak selaku badan penguasa atas tanah. Dari sudut inilah harus dilihat arti ketentuan dalam Pasal 2 ayat (1) UUPA yang menyatakan bahwa "bumi, air, dan ruang angkasa, termasuk kekuasaan alam yang terkandung di dalamnya, pada tingkatan yang tertinggi dikuasai oleh negara." Berdasarkan pada pangkal pendirian tersebut, perkataan "dikuasai" dalam pasal ini bukanlah berarti "dimiliki", tetapi memberi wewenang kepada negara sebagai organisasi kekuasaan bangsa Indonesia untuk menguasai tanah pada tingkatan yang tertinggi yang dinamakan Hak Menguasai dari Negara (HMN). Dapat pula dikatakan bahwa HMN pada tingkatan tertinggi ini merupakan hubungan hak ulayat yang diangkat pada tingkatan yang paling tinggi yaitu tingkatan seluruh wilayah Indonesia (Soetiknjo, 1994).

HMN meliputi semua tanah yang berada dalam wilayah Republik Indonesia, baik tanah-tanah yang tidak atau belum diberikan hak maupun yang sudah diberikan hak dengan hak-hak perorangan. Tanah-tanah yang belum diberikan hak dengan hak-hak perorangan oleh UUPA disebut tanah-tanah yang dikuasai langsung oleh negara. Untuk menyingkat pemakaian katakata dalam praktik administrasi sering digunakan istilah tanah negara.

Prof. Boedi Harsono dalam bukunya menyatakan bahwa ditinjau dari segi kewenangan penguasaannya, terdapat kecenderungan untuk lebih memperinci status-status tanah yang semula tercakup dalam pengertian tanah-tanah Negara itu menjadi antara lain: (1) tanah-tanah wakaf; (2) tanah-tanah HPL; (3) tanah-tanah hak ulayat; (4) tanah-tanah kaum; (5) tanah-tanah kawasan hutan; (4) tanah-tanah sisanya (tanah negara dalam arti sempit) (Harsono, 2018).

Ditinjau dari segi kewenangan penguasaannya di atas terlihat bahwa baik itu HPL ataupun tanah wakaf merupakan perincian dari tanah negara, oleh karenanya menurut penulis bertanya-tanya, mengapa hanya di atas tanah HPL saja yang dapat diberikan hak atas tanah lainnya. Selain itu, terdapat juga singgungan atau sentuhan hukum yang menandakan bahwa pengelolaan tanah wakaf dapat juga dilakukan seperti HPL antara lain: (a) Tanah wakaf maupun tanah HPL merupakan tanah-tanah yang dikuasai langsung oleh negara; (b) Tanah wakaf dan tanah HPL keduanya dapat diterbitkan Sertipikat Tanah Wakaf dan Sertipikat HPL; (c) Tanah-tanah wakaf dan tanah-tanah HPL tidak dapat beralih atau dialihkan; (d) Penjagaan, pengelolaan, dan pengembangan tanah wakaf dilaksanakan oleh nazhir sedangkan untuk tanah-tanah HPL dilakukan oleh instansi pemerintah, BUMN, BUMD, PT Persero, badan otorita, badan hukum lainnya yang ditunjuk pemerintah.

Tabel 2. Persamaan tanah wakaf dan tanah HPL 


\begin{tabular}{|c|l|c|c|}
\hline No & \multicolumn{1}{|c|}{ Indikator } & Tanah Wakaf & Tanah HPL \\
\hline 1 & Penguasaan Tanah & $\begin{array}{c}\text { Hak menguasai dari negara } \\
\text { yang kewenangan } \\
\text { pelaksanaannya sebagian } \\
\text { dilimpahkan kepada } \\
\text { pemegangnya. }\end{array}$ & $\begin{array}{c}\text { Hak menguasai dari negara } \\
\text { yang kewenangan } \\
\text { pelaksanaannya sebagian } \\
\text { dilimpahkan kpada } \\
\text { pemegangnya }\end{array}$ \\
\hline 2 & Bukti Hak Atas Tanah & Sertipikat Tanah Wakaf & $\begin{array}{c}\text { Sertipikat Tanah Hak } \\
\text { Pengelolaan }\end{array}$ \\
\hline 3 & Sifat Tanah & Tidak dapat beralih atau & $\begin{array}{c}\text { Tidak dapat beralih atau } \\
\text { dialihkan }\end{array}$ \\
\hline 4 & Pengelola Tanah & Nazhir & $\begin{array}{c}\text { Instansi Pemerintah, } \\
\text { BUMN, BUMD, badan } \\
\text { otorita, badan hukum } \\
\text { lainnya yang ditunjuk } \\
\text { pemerintah. }\end{array}$ \\
\hline
\end{tabular}

HPL pada dasarnya memiliki dua aspek yaitu: (a) Aspek Publik, bahwa HPL sebagai pengejawantahan dari HMN yang kewenangannya sebagian dilimpahkan kepada pemegangnya, dimana tujuan utama dari HPL adalah bahwa tanah HPL disediakan bagi penggunaan pihakpihak lain yang memerlukan. (b) Aspek Perdata, bahwa HPL berubah fungsinya dari "pengelolaan" oleh negara menjadi "hak" yang dapat digunakan keperluan usaha pemegangnya sendiri dan karena kebutuhan praktis yakni untuk memberikan hak atas tanah di atas HPL kepada pihak ketiga melalui perjanjian antara pemegang HPL dengan pihak ketiga yang memerlukan (Hutagalung \& Sitorus, 2011).

HPL tidak dimasukan dalam golongan hak-hak atas tanah, pemegang HPL mempunyai kewenangan menggunakan tanah untuk keperluan usahanya. Tujuan utama pemberian HPL tersebut adalah pemegang HPL diberi kewenangan untuk melakukan kegiatan yang merupakan sebagian dari kewenangan negara sebagaimana di atur dalam Pasal 2 UUPA. Sehubungan dengan itu maka HPL pada hakikatnya bukan hak atas tanah melainkan gempilan HMN yang diberikan kepada pemegangnya. Berdasarkan PP No. 18/2021, HPL adalah hak menguasai dari negara yang kewenangan pelaksanaannya sebagian dilimpahkan kepada pemegang HPL.

Maksud dari pemberian HPL menurut Prof. Boedi Harsono bahwa bidang-bidang tanah yang dikuasai dengan HPL itu tidak diperuntukan bagi keperluan sendiri pemegang haknya, melainkan disediakan bagi pemenuhan kebutuhan pihak lain. Misalnya pengusaha kawasan industri yang menyediakan bagian-bagian tanah yang dikuasainya bagi keperluan perusahaanperusahaan industri yang beroperasi di kawasannya (Hutagalung \& Sitorus, 2011).

Untuk mendapatkan hak-hak atas tanah seperti HGB, pemegang HPL mengadakan perjanjian dengan pihak yang memohon hak-hak atas tanah tersebut dengan membuat Surat Perjanjian Penggunaan dan Pemanfaatan Tanah (SPPT). Berdasarkan Peraturan Menteri Dalam Negeri Nomor 1 Tahun 1977 (Permendagri No. 1/1977), dalam perjanjian tersebut, selain menyebutkan identitas para pihak, letak, luas dan batas-batas bidang tanahnya dan jenis penggunaannya, juga kesepakatan mengenai: (a) Hak atas tanah yang dimintakan untuk diberikan kepada pihak yang bersangkutan dan keterangan mengenai jangka waktu berlakunya 
serta kemungkinan memperpanjangnya; (b) Jenis-jenis bangunan yang akan didirikan di atasnya dan ketentuan mengenai pemilikan bangunan-bangunan tersebut pada berakhirnya hak atas tanah yang diberikan; (c) Jumlah uang pemasukan dan syarat-syarat pembayarannya; (d) Serta syarat-syarat lain yang dianggap perlu.

Pendapat lain mengatakan HGB di atas tanah HPL adalah hak untuk memanfaatkan tanah dan bangunan aset Instansi atau BUMN, sehingga termasuk pembebanan hak, bukan pemberian hak. Hak semacam ini dapat dikategorikan sebagai sewa tanah dengan berjangka waktu panjang (Hartono, 2000). Pemberian HGB di atas HPL tidak sama dengan penjualan tanah, karena dalam pemberian HGB di atas HPL tidak ada peralihan hak atas tanah dari pemegang HPL kepada pemegang HGB, sedangkan dalam penjualan tanah terdapat peralihan hak atas tanah dari penjual kepada pembeli (Hutagalung \& Sitorus, 2011).

Secara keseluruhan peraturan perundang-undangan yang mengatur HGB di atas tanah negara berlaku juga untuk HGB di atas HPL. Namun terdapat perbedaan dalam hal perlunya persetujuan pemegang HPL apabila HGB di atas HPL akan diperpanjang atau diperbarui, digunakan sebagai jaminan hutang atau dialihkan kepada pihak ketiga. Apabila tanah yang bersangkutan tidak digunakan/ditelantarkan oleh pemilik HGB atau dengan berakhirnya jangka waktu penggunaan HGB. Maka pemegang HPL dapat membatalkan HGB yang bersangkutan sebelum jangka waktu berakhir atau tidak memperpanjang hak atas tanah sehingga HGB tersebut hapus dan tanah yang bersangkutan akan kembali kepada pemegang HPL (Hutagalung \& Sitorus, 2011).

Oleh karena kedudukan tanah wakaf dan tanah HPL yang memiliki persamaan hukum dan juga keduanya merupakan perincian dari tanah negara menurut Prof. Boedi Harsono maka secara keseluruhan peraturan perundang-undangan yang mengatur tanah-tanah HPL seharusnya dapat diberlakukan terhadap tanah wakaf. Nazhir selaku pengelola tanah wakaf dapat melakukan perjanjian penggunaan tanah di atas tanah wakaf, dimana tanah yang menjadi objek perjanjian tersebut nantinya akan menjadi HGB di atas tanah wakaf. HGB merupakan hak yang berjangka waktu, maka setelah jangka waktu HGB habis, tanah tersebut kembali dalam penguasaan nazhir. Secara sederhana, tanah wakaf akan menjadi alas dari HGB yang diterbitkan layaknya tanah HPL atau HM yang menjadi alas dari HGB. Konsep yang demikian tidak akan menghapus status tanah wakaf, karena tanah wakaf tetap ada dan menjadi alas dari HGB yang bersangkutan.

Konsep pemberian HGB di atas tanah wakaf merupakan konsep strategis apabila dapat diimplementasikan. Maka darinya, diperlukan upaya intensif agar konsep yang digagas oleh penulis ini dapat menjadi rujukan ataupun masukan bagi pemangku kebijakan seperti Pemerintah, DPR, Aparat Penegak Hukum, Civitas Akademik, MUI, dan terlebih lagi BWI selaku lembaga yang menaungi lembaga wakaf di Indonesia.

Selain itu, untuk mendukung konsep pemberian HGB di atas tanah wakaf maka diperlukan pengelola atau dalam hal ini nazhir yang memang kompeten. Posisi pengelola tanah wakaf ini dapat dilaksanakan oleh BWI atau BUMN/BUMD yang nantinya dibentuk khusus untuk merealisasikan konsep ini. BUMN/BUMD yang nantinya dibentuk untuk menjadi nazhir setidaknya harus memenuhi persyaratan sebagai berikut: (1) badan hukum milik negara atau 
milik daerah; (2) seluruh modalnya dimiliki oleh Pemerintah atau Pemerintah Daerah dan merupakan kekayaan negara yang tidak dipisahkan; (3) berorientasi pada pelayanan publik yang mengutamakan sebesar-besarnya kemakmuran rakyat.

\section{Potensi Manfaat Implementasi Konsep HGB di atas Tanah Wakaf}

Konsep yang penulis gagas yaitu pemberian HGB di atas tanah wakaf memiliki beberapa keuntungan atau manfaat apabila dapat diterapkan di Indonesia yang diketahui bersama bahwa Indonesia merupakan negara dengan penduduk muslim terbanyak di dunia. Sehingga pemanfaatan wakaf sangat potensial untuk kesejahteraan masyarakat. Berbicara mengenai manfaat, selain lembaga wakaf, memang Islam telah mengenal lembaga-lembaga lain seperti sedekah, infak, zakat. Posisi wakaf pun ada sebagai bentuk perhatian Islam terhadap kesejahteraan umat. Apabila dana infak dan sedekah habis digunakan untuk pembiayaan operasional, dana zakat digunakan untuk dana solusi darurat umat (delapan penerima zakat/mustahik zakat). Maka lembaga wakaf hadir sebagai lembaga sedekah jariyah guna membangun kesejahteraan ekonomi umat secara umum.

Secara umum manfaat wakaf dapat dilihat dan bergantung sistem pengelolaannya. Pengelolaan secara tradisional dan modern memberikan manfaat yang berbeda. Keduanya memang memberikan bermanfaat, namun dampak manfaat itu diyakini memiliki perbedaan mencolok. Pengelolaan tradisional yang menempatkan kekekalan benda berada pada posisi teratas kerap mengesampingkan inovasi pengelolaan. Adapun pengelolaan modern dinilai mengedepankan aspek kemanfaatan benda melalui pengelolaan produktif dengan tetap menjaga eksistensi bendanya yakni tetap ada dan tidak berkurang. Jadi substansi ajaran wakaf itu tidak sematamata terletak pada pemeliharaan bendanya (aset wakaf), tapi jauh lebih penting adalah nilai manfaat benda tersebut dalam turut memecahkan masalah perekonomian umat.

Secara khusus konsep pengaturan HGB di atas tanah wakaf merupakan inovasi pemanfaatan tanah-tanah wakaf dalam rangka pengembangan investasi wakaf produktif. Implementasi HGB di atas tanah wakaf dapat memberikan manfaat pada developer maupun pada nazhir. Bagi developer sebagai pihak yang menginginkan HGB di atas tanah wakaf untuk keperluan bisnis akan mendapatkan manfaat antara lain: (a) kebebasan biaya pengadaan tanah yang relatif besar apabila melalui proses pengadaan tanah untuk keperluan komersial; dan (2) tambahan modal apabila dibutuhkan karena dapat menjaminkan HGB di atas tanah wakaf dengan lembaga Hak Tanggungan dengan izin nazhir selaku pengelola tanah wakaf.

Pada sisi yang lain, keuntungan juga dapat dirasakan bagi nazhir selaku pengelola tanah wakaf. konsep ini juga akan memberikan keuntungan berupa: (a) mendapatkan pemasukan dari biaya pemanfaatan tanah wakaf yang harus dibayar di awal oleh developer saat ingin mendapatkan HGB di atas tanah wakaf; dan (b) mendapatkan pemasukan dari biaya rekomendasi yang diberikan oleh developer baik itu saat pertama kali mendapatkan HGB ataupun pada saat developer ingin memperpanjang HGB-nya. Dana yang didapatkan oleh nazhir dari developer dapat dipergunakan untuk kepentingan umum dan kesejahteraan umat sesuai niat atau akta ikrar wakaf yang dibuat oleh wakif.

\section{Kesimpulan}


Konsep wakaf produktif dapat diterapkan dalam wakaf tanah yang seringkali disebut wakaf konsumtif. Konsep pemberian HGB di atas tanah wakaf merupakan salah satu alternatif pilihan solusi untuk mewakafkan tanah secara produktif di kemudian hari. Konsep ini dalam penerapannya dapat menerapkan peraturan-peraturan pemberian hak atas tanah di atas tanah HPL. Hal yang demikian dapat diterapkan karena pada dasarnya tanah wakaf dan tanah HPL memiliki beberapa persamaan dalam praktik dan konsep. Manfaat yang dapat diperoleh dari penerapan konsep pemberian HGB di atas tanah wakaf ini dapat dilihat dari sisi developer selaku pemegang HGB dan sisi nazhir selaku pengelola tanah wakaf. Developer yang memiliki HGB di atas tanah wakaf mendapatkan kebebasan dari biaya pengadaan tanah yang relatif mahal serta dapat menjaminkan HGB di atas tanah wakafnya. Sedangkan di sisi lain, nazhir selaku pengelola tanah wakaf juga mendapatkan manfaat berupa biaya pemanfaatan tanah wakaf dan biaya rekomendasi yang dibayarkan oleh developer kepada nazhir sebagai syarat untuk pemakaian tanah wakaf dan kepentingan sertifikasi HGB di atas tanah wakaf tersebut. Manfaat yang diterima oleh nazhir tersebut dapat digunakan guna kepentingan umum atau kesejahteraan umat sesuai dengan niat atau akta ikrar wakaf. Namun untuk dapat menerapkan konsep ini, maka diperlukan partisipasi pemangku kebijakan seperti Pemerintah, DPR, BWI untuk menerbitkan landasan hukum guna praktik pemberian HGB di atas tanah wakaf.

\section{Referensi}

Badan Wakaf Indonesia. (2018). Himpunan Peraturan Perundang-Undangan Tentang Wakaf (4th ed.). Badan Wakaf Indonesia.

Djumeno, L. D., \& Fauzi, F. (2021). Menggagas Pemberian Hak Guna Bangunan Di Atas Tanah Wakaf: Terobosan Baru Pemberdayaan Tanah Wakaf. CV Elfa Mediatama.

Elimartati. (2016). Potensi Peningkatan Pemberdayaan Wakaf di Kabupaten Tanah Datar. ElHekam, 1(1). https://doi.org/10.31958/jeh.v1i1.343

Fauzi, F. (2019). Pendaftaran Tanah Wakaf Untuk Tanah Milik Adat Yang Belum Terdaftar Berdasarkan Peraturan Perundang-undangan Tentang Wakaf. In Percikan Pemikiran Makara Merah dari FHUI Untuk Indonesia. Badan Penerbit Fakultas Hukum Universitas Indonesia.

Hadi, S. (2018). Pemberdayaan Ekonomi Melalui Wakaf. ZISW AF: Jumal Zakat Dan Wakaf, 4(2). https://doi.org/10.21043/ziswaf.v4i2.3043

Hanna, S. (2015). Wakaf Saham dalam Perspektif Hukum Islam. Mizan: Jurnal Ilmu Syariah, 3.

Harsono, B. (2018). Hukum Agraria Indonesia (Sejarah Pembentukan Undang-Undang Pokok Agraria, Isi dan Pelaksanaannya). Universitas Trisakti.

Hartono, D. (2000). Penerbitan HGB di atas HPL.

Hidayati, T. (2012). Tanah Wakaf Terlantar: Perspektif PP Nomor 11 Tahun 2010. Jurnal Kajian Islam, 4(2), 211-231.

Hutagalung, A. S., \& Sitorus, O. (2011). Seputar Hak Pengelolaan (1st ed.). STPN Press.

Indonesia. Undang-Undang Pokok-Pokok. Agraria. UU No.5 Tahun 1960, LN No.104 Tahun 1960.

Indonesia. Undang-Undang Wakaf. UU No. 41 Tahun 2004, LN No.159 Tahun 2004, TLN No. 4459 .

Indonesia. Undang-Undang Cipta Kerja. UU No. 11 Tahun 2020, LN No. 245 Tahun 2020, TLN 
No. 6573.

Indonesia. Peraturan Pemerintah Tentang Pelaksanaan Undang-Undang Nomor 41 Tahun 2004 Tentang Wakaf. PP No. 42 Tahun 2006.

Indonesia. Peraturan Pemerintah Tentang Pendaftaran Tanah. PP No. 24 Tahun 1997.

Indonesia. Peraturan Pemerintah tentang Hak Pengelolaan, Hak Atas Tanah, Satuan Rumah Susun, dan Pendaftaran Tanah. PP No. 18 Tahun 2021.

Indonesia. Menteri Agraria dan Tata Ruang/Kepala Badan Pertanahan Nasional. Peraturan Menteri ATRBPN tentang Tata Cara Pendaftaran Tanah Wakaf di Kementerian Agraria dan Tata Ruang/Badan Pertanahan Nasional. Nomor PM 2 Tahun 2017.

Indonesia. Menteri Agama. Peraturan Menteri Agama tentang Tata Cara Perwakafan Benda Tidak Bergerak \& Benda Bergerak. Selain Uang. Nomor PM 73 Tahun 2013.

Indonesia. Kompilasi Hukum Islam.

Intan, N. (2019). BWI: Potensi Aset Wakaf Capai Rp 2000 Triliun per Tahun. Republika. https://republika.co.id/berita/dunia-islam/wakaf/19/09/30/pymexa383-bwi-potensiaset-wakaf-capai-rp-2000-triliun-per-tahun

Khusaeri, K. (2015). Wakaf Produktif. Al-A'raf: Jurnal Pemikiran Islam Dan Filsafat, 12. https://doi.org/10.22515/ajpif.v12i1.1185

Lita, H. N., \& Sandra, E. (2018). Perjanjian Build, Operate, and Transfer (BOT) Pada Kerjasama Pembangunan Commercial Building Diatas Tanah Wakaf Berdasarkan Ketentuan Hukum Positif Indonesia. In Al-Awqaf: Jurnal Wakaf dan Ekonomi Islam (Vol. 11, Issue 1).

Lita, H. N., \& Utama, Z. M. (2016). Pembangunan Rumah Susun Diatas Tanah Wakaf. AlAwqaf: Jurnal Wakaf Dan Ekonomi Islam, 9(2), 113-121.

Lubis, M. Y., \& Lubis, A. R. (2008). Hukum Pendaftaran Tanah. Mandar Maju.

Moleong, L. J. (2017). Metodologi Penelitian Kualitatif. In PT. Remaja Rosda Karya (36th ed.).

Mubarok, J. (2008). Wakaf Produktif. Simbiosa Rekatama Media.

Munawwir, A. W. (1984). Al-Munawnir Kamus Arab-Indonesia. Unit Pengadaan Buku-Buku Ilmiah Keagamaan Pondok Pesantren Al-Munawwir.

Prihatini, F., Hasanah, U., \& Wirdyaningsih. (2005). Hukum Islam Zakat dan Wakaf Teori dan Prakteknya di Indonesia (1st ed.). Badan Penerbit Fakultas Hukum Universitas Indonesia.

Qahaf, M. (2005). Manajemen Wakaf Produktif. Khalifa.

Santoso, U. (2014). Kepastian Hukum Wakaf Tanah Hak Milik. Perspektif, 19(2). https://doi.org/10.30742/perspektif.v19i2.10

Santoso, U. (2017). Hak Atas Tanah, Hak Pengelolaan, dan Hak Milik Atas Satuan Rumah Susun (1st ed.). Kencana.

Soekanto, S. (1986). Pengantar Penelitian Hukum (3rd ed.). Penerbit Universitas Indonesia.

Soetiknjo, I. (1994). Politik. Agraria Nasional Hubungan Manusia Dengan Tanah Yang Berdasarkan Pancasila (4th ed.). Gadjah Mada University Press.

Sutrisno, S. (2017). Pemberdayaan Tanah Wakaf Yang Dikelola Yayasan Berdasarkan Nilai Keadilan. Jurnal Pembaharuan Hukum, 4(1), 140-146. https://doi.org/10.26532/jph.v4i1.1655 